\title{
PROMOSI EDUWISATA \\ PUSAT PENELITIAN KOPI DAN KAKAO INDONESIA DI KABUPATEN JEMBER
}

\author{
Ari Susanti \\ Program Studi Ilmu Komunikasi Universitas Muhammadiyah Jember \\ Email : ari.susanti@unmuhjember.ac.id
}

\begin{abstract}
This study focuses on the promotion of edutourims developed by the Indonesian Center for Research on Coffee and Cocoa. Eduwisata Coffee and Cacao Science Techno Park (CCSTP) was inaugurated in May 2016. In a 18 months many people have visited and become alternative tourism objects for the people of Jember and its surroundings. Researchers are interested in studying integrated marketing communication developed by the Indonesian Coffee and Cocoa Research Center in promoting tourism. The research method used is descriptive qualitative analysis where the researcher describes various promotional tools developed by the Research Center. Data collection techniques were carried out by conducting in-depth interviews with the management of the CCSTP Tourism Research Center with data analysis techniques using both data triangulation, methods and theories. The results of the study were the integrated marketing communication strategies used by CCSTP including personal communication (word of mouth promotion), IWJ social media and personal selling (presenting to schools government and company). Among the three most effective promotional tools were personal communication where personal approach to optimizing prospective visitors optimally.
\end{abstract}

Keywords : Integrated Marketing Communication, Edutourism, Puslikoka

\begin{abstract}
ABSTRAK
Penelitian ini berfokus pada promosi eduwiwata yang dikembangkan oleh Pusat Penelitian Kopi dan Kakao Indonesia (Puslitkoka). Eduwisata Coffee and Cacao Science Techno Park (CCSTP) ini diresmikan pada bulan Mei 2016 ini. Dalam kurun waktu 18 bulan telah banyak dikunjungi masyarakat dan menjadi objek wisata alternatif bagi masyarakat Jember dan sekitarnya. Pe neliti tertarik mengkaji komunikasi pemasaran terpadu yang dikembangkan oleh Pusat Penelitian Kopi dan Kakao Indonesia dalam mempromosikan eduwisata. Metode penelitian yang digunakan adalah analisis kualitatif deskriptif dimana peneliti menjabarkan berbagai alat promosi yang dikembangkan Puslitkoka. Teknik pengambilan data dilakukan dengan cara melakukan wawancara mendalam pada pengelola Eduwisata CCSTP Puslitkoka dengan teknik analisis data menggunakan triangulasi baik data, metode dan teori. Hasil penelitian adalah strategi komunikasi pemasaran terpadu yang digunakan CCSTP antara lain komunikasi personal (promosi dari mulut ke mulut), media sosial IWJ dan personal selling (melakukan presentasi ke sekolah-sekola, lembaga pemerintah dan perusahaan. Diantara tiga alat
\end{abstract}


promosi ini yang paling efektif adalah komunikasi personal dimana pendekatan personal dalam lebih mempersuasi calon pengunjung secara optimal.

Kata kunci : Komunikasi Pemasaran Terpadu, Eduwisata, Puslitkoka

\section{PENDAHULUAN}

Kehadiran media sosial memiliki dampak yang sangat besar pada masyarakat. Dunia sudah tidak bisa lepas dari media sosial. Segala aktivitas kita semua berbasis internet. Media sosial dengan mudah diakses melalui handphone dengan teknologi android, dapat dimiliki siapa saja. Tidak hanya itu, akses jaringan internet semakin luas sehingga tidak ada tempat yang tidak memliki jaringan internet. Salah satu dampak yang menonjol saat ini, adalah pengguna smartphone berlomba-lomba menunjukkan eksistensi diri di media sosial. Berbagai hal dilakukan untuk mendapatkan pengakuan dari pengguna media sosial lainnya. Selalu mengikuti trend terbaru mengenai apa saja menjadi kunci utama keberhasilan eksistensinya dengan menggunggah segala aktivitasnya di media sosial. Oleh karena itu, segala sesuatu yang bersifat kekinian dan petualang banyak dicari masyarakat.

Kecenderungan masyarakat menahan diri untuk tidak membelanjakan penghasilannya dan lebih dialokasikan untuk membeli pengalaman dengan berbagai cara telah ditangkap oleh Pusat Penelitian Kopi dan Kakao Indonesia sebagai terobosan untuk memberdayakan potensi perkebunan yang dimilikinya menjadi area wisata. Hal senada dikemukakan Umami dalam artikelnya yang berjudul Social Strategy pada Media Massa untuk Promosi Pariwisata Daerah Istimewa Yogyakarta, dimana kekuatan media sosial mampu meningkatkan kunjungan wisata secara berkala. Pada objek wisata yang dikembangkan oleh Puslit Kopi dan Kakao Indonesia terbagi menjadi tiga bagian yaitu wisata edukasi, wisata kuliner dan wisata alam.

Sebagai pusat penelitian, Perkebunan di Desa Nogosari merupakan tempat untuk mempelajari dan meneliti tentang kopi dan kakao. Karenanya adalah tepat mengembangkannya menjadi objek wisata edukasi. Wisata edukasi yang ditawarkan adalah berbagai macam varietas unggulan kopi dan kakao dan area pabrik pemrosesan kopi dan kakao yang dihasilkan di perkebuna menjadi berbagai produk unggulan yang telah terjual hingga ke mancanegara. Area pabrik dapat ditinjau oleh pengunjung dengan pendamping (guide) yang disediakan perkebunan. Tugas pendamping ini akan menjelaskan seluruh proses pembuatan 
kopi dan kakao dari hulu ke hilir sehingga pengunjung memperoleh pengetahuan dan pengalaman baru mengenai kopi dan kakao.

Perkebunan Puslitkoka memiliki pabrik yang menghasilkan kopi dan kakao, maka terdapat area istirahat dan restoran yang menjual produk perkebunan. Sajian aneka produk kopi dan kakao dibuat dalam bentuk panganan menjadi andalan wisata kuliner di Perkebunan Desa Nogosari ini. Sensasi mencicipi makanan yang diolah dari produk unggulan merupakan pengalaman baru bagi pengunjung. Selain dimakan di tempat, pengunjung dapat pula membawa pulang oleh-oleh hasil olahan kopi dan kakao.

Area perkebunan yang luas dan sejuk dapat dijadikan wisata alam. Pengunjung dapat menikmati sejuk dan indahnya perkebunan sebagai sarana rekreasi yang nyaman dan murah bersama keluarga dan sahabat. Perkebunan juga menyediakan penginapan. Penginapan ini awalnya disediakan bagi peserta Diklat dan penelitian kopi dan kakao. Kemudian berkembang dengan menyediakan guest house untuk tamu non peserta Diklat atau peneliti.

Perubahan yang terjadi di dalam manajemen Pusat Penelitian Kopi dan Kakao Indonesia dari pusat penelitian berkembang menjadi objek wisata perkebunan berimbas pada kinerja lembaga. Kesiapan lembaga dalam hal pemekaran usaha perlu dipersiapkan. Namun dalam perjalannya, Coffee and Cacao Science Techno Park (CCSTP) dalam kurun waktu 18 bulan dapat menjadi objek wisata popular di Jember. Hal ini menarik bagi peneliti untuk mengetahui bagaimana strategi promosi yang dilakukan oleh Pusat Penelitian Kopi dan Kakao Indonesia dalam mempromosikan eduwisata CCSTP.

\section{METODE}

Penelitian ini merupakan penelitian deskriptif kualitatif. Jenis penelitian deskriptif bertujuan menjabarkan secara sistematis, factual dan akurat tentang fakta-fakta dan sifat-sifat objek penelitian. Sedangan penelitian kualitatif merupakan jenis penelitian yang memberikan kesempatan seluas-luasnya kepada peneliti untuk mengalih data sebanyak-banyaknya sehingga diperoleh data yang lebih mendalam dan komprehensif. Dengan demikian penelitian deskriptif kualitatif berusaha menjabarkan secara sistematis, factual dan akurat mengenai data-data yang dapat dipertanggung jawabkan dengan terperinci dan komprehensif selama proses penelitian. 
Sasaran penelitian ini adalah Pusat Penelitian Kopi dan Kakao Indonesia yang berkantor di Jl. Panglima Besar Sudirman No. 90 Jember dan Perkebunan Desa Nogosari, Kecamatan Rambipuji, Kabupaten Jember yang berjarak $\pm 20 \mathrm{~km}$ arah Barat Daya dari Kota Jember.

Pusat Penelitian Kopi dan Kakao Indonesia memiliki beberapa bidang kerja atau departemen. Dalam penelitian ini, unit analisis yang diambil adalah divisi wisata perkebunan sesuai dengan tujuan penelitian untuk menganalisis strategi komunikasi pemasaran terpadu wisata perkebunan yang dimiliki Puslit Kopi dan Kakao Indonesia.

Dalam mengumpulkan data, peneliti menggunakan beberapa teknik sebagai berikut :

1) Wawancara mendalam/in dept interview. Wawancara akan dilakukan untuk memperoleh data primer sebanyakbanyaknya. Rencananya, akan diambil dua orang informan, yaitu Kepala Perkebunan Desa Nogosari dan Manager Divisi Wisata Perkebunan

2) Observasi. Kunjungan dilakukan untuk melihat lebih dekat operasionalisasi wisata perkebunan Puslit Kopi dan Kakao Indonesia.

3) Foto dokumentasi sebagai dokumen penunjang kelengkapan penelitian.
Teknik analisis data dalam penelitian ini menggunakan metode deskriptif kualitatif dengan menggunakan teknik triangulasi. Teknik triangulasi ada beberapa jenis antara lain : (Pawito, 2007;99-100)

1) Triangulasi data. Merujuk pada upaya peneliti untuk mengakses sumbersumber yang lebih bervariasi guna memperoleh data berkenaan dengan permasalahan yang sama. Ini berarti peneliti harus menguji data yang diperoleh dengan membadingkan data dari sumber lain. Data yang diperoleh akan beragam karena ada kemungkinan akan didapat data yang konsisten, tidak konsisten, atau berlawanan. Dengan demikian, peneliti dapat mengungkapkan gambaran yang lebih terperinci dan mendalam mengenai gejala yang diteliti.

2) Triangulasi metode. Merujuk pada upaya peneliti untuk membandingkan antardata yang ditemukan dalam penelitian. Peneliti sedang menguji tingkat validitas dan reliabilitas data dengan menggunakan metode berbeda.

3) Triangulasi teori. Merujuk pada upaya peneliti untuk menggunakan prespektif teori yang bervariasi dalam menginterpretasikan data yang sama. Data yang sama dapat dilihat dari prespektif teori yang beragam. 


\section{PEMBAHASAN}

\section{Eduwisata Sebagai Ikon Puslitkoka}

Coffee and Coca Science Techo Park (CCSTP) atau yang lebih dikenal dengan Eduwisata Pusat Penelitian Kopi dan Kakao Indonesia merupakan suatu kawasan yang dikelola untuk menginisiasi dan menyalurkan inovasi teknologi hulu (on farm) sampai hilir (off farm) kepada semua pelaku usaha pemula di sektor industri berbasis kopi dan kakao, sehingga mampu mencetak entrepreneurentrepreneur baru pendorong pertumbuhan ekonomi nasional bersinergi dengan akademisi, pelaku bisnis dan pemerintah pusat/daerah.

CCSTP alias Taman Sains dan Teknologi Kopi dan Kakao ini merupakan bagian dari Puslitkoka Indonesia diresmikan pada tanggal 20 Mei 2016 oleh Menteri Riset dan Pendidikan Tinggi Prof. H.M. Nasir, M.Si. Ph.D.AK. Terletak di Desa Nogosari, Kecamatan Rambipuji, Kabupaten Jember, sekitar 30 menit ke arah barat daya dari pusat kota Jember, CCSTP memiliki berbagai fasilitas dan pelayanan eduwisata antara lain :

\section{Tour Perkebunan dengan Kereta Flintstone}

Kebun Percobaan dan Areal Kantor yang dimiliki Puslitkoka seluas 380 ha yang terdiri atas kebun percobaan kopi arabika (Kebun Percobaan Andungsari ketinggian 100-1.200 m dpl.), kopi robusta dan kakao (Kebun Percobaan Kaliwining dan Kebun Percobaan Sumberasin ketinggian 45-550 m dpl.). Masyarakat dapat menikmati pemandangan perkebunan yang indah dan sejuk sambil belajar varietas tanaman kopi dan kakao. Dalam tour ini, akan didampingi oleh pemandu yang bertugas menjelaskan tentang tanaman-tanaman yang berada di areal perkebunan.

Mengingat luasnya areal perkebunan maka CCSTP menyediakan mobil yang didesain seperti kayu. Mobil ini diberi nama kereta flintstone. Nama Flintstone diambil dari karakter film kartun yang menceritakan era peradaban jaman batu, dimana mobil atau kereta kayu ini unik seperti jaman batu. Mobil kayu ini akan membawa wisatawan mengunjungi beberapa objek antara lain :

a) Demplot penerapan teknologi budidaya tanaman unggulan kopi dan kakao

b) Koleksi plasma nutfah kopi dan kakao

c) Rehabilitas tanaman kopi dan kakao dengan teknologi sambung samping

d) Integrasi kebun kopi dan kakao dengan ternak 
e) Penggunaan teknologi irigasi tetes dan fergitasi untuk kebun kopi dan kakao f) Kawasan konservasi untuk penangkaran satwa yang dilindungi yaitu Rusa Timor dan Rusa Tutul.

Dalam area CCSTP juga tersedia kolam renang untuk anak-anak yang terletak di tengah-tengah rute perkebunan. Kegiatan keliling perkebunan ini biasanya disebut on farm dimana pengunjung dapat melihat secara langsung riset-riset kopi dan kakao di kebun percontohan.

\section{Pabrik Proses Pengolahan Sekunder}

\section{Kopi dan Kakao}

Kegiatan berikutnya adalah off farm. Dalam kegiatan ini pengunjung dapat melihat proses pengolahan kopi dan kakao pascapanen. Namun tidak semua tempat dapat dikunjungi pabrik pengolahan hulu dan hilir kopi dan kakao yang berstandar SNI. Hal ini untuk mengurangi kontaminasi produk sehingga areal produksi di pabrik tetap terjaga bersih, steril dan higienis.

Adapun fasilitas pascapanen yang dapat dikunjungi secara bebas antara lain :

a) Area penjemuran untuk kopi da kakao

b) Area fermentasi untuk kakao

c) Rekayasa alat dan mesin pengolahan kopi dan kakao
Masih di dalam area off farm, terdapat reaktor biogas sebagai upaya pemanfaatan limbah kopi dan kakao. Penemuan ini terus dikembangkan untuk menciptakan sumber energi alternatif yang akan bermanfaat bagi masyarakat.

\section{Transfer Teknologi dan Inkubasi Bisnis}

Sebagai STP, Puslitkoka memiliki tanggung jawab untuk membentuk entrepreneurs di bidang kopi dan kakao. Para calon pengusaha baru di bidang kopi dan kakao bisa belajar lebih lanjut di fasilitas-fasilitas Puslitkoka Jember. Gedung Transfer Teknologi dan Inkubasi Bisnis yang terletak di sebelah Outlet CCSTP. Adapun materi-materi yang disampaikan dalam pelatihan bagi entrepreneur adalah sebagai berikut :

Tabel 1 : Materi-materi dalam Pelatihan Inkubasi Bisnis

\begin{tabular}{|c|c|}
\hline Kopi & Kakao \\
\hline $\begin{array}{l}\text { Teknik } \\
\text { budidaya dan } \\
\text { pengolahan } \\
\text { kopi }\end{array}$ & $\begin{array}{l}\text { Teknik } \\
\text { budidaya dan } \\
\text { pengolahan } \\
\text { kakao }\end{array}$ \\
\hline $\begin{array}{l}\text { Uji cita rasa } \\
\text { kopi }\end{array}$ & $\begin{array}{l}\text { Uji cita rasa } \\
\text { kakao }\end{array}$ \\
\hline $\begin{array}{l}\text { Coffee } \\
\text { roasting dan } \\
\text { blending }\end{array}$ & $\begin{array}{l}\text { Pembuatan } \\
\text { makanan } \\
\text { cokelat }\end{array}$ \\
\hline $\begin{array}{l}\text { Pengolahan } \\
\text { organisme } \\
\text { pengganggu } \\
\text { tanaman kopi }\end{array}$ & $\begin{array}{l}\text { Pengolahan } \\
\text { organisme } \\
\text { pengganggu } \\
\text { tanaman kakao }\end{array}$ \\
\hline
\end{tabular}




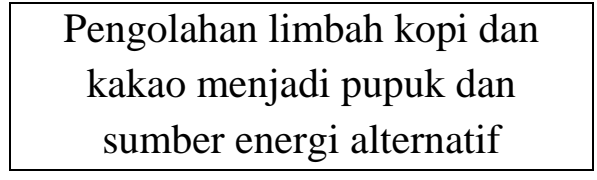

Sumber : http://tc.iccri.net/

Bagi pengunjung umum dan pelajar (bukan peserta pelatihan) dapat melihat informasi terkait pelatihan entrepreneur tersebut dengan harapan dapat menarik lebih banyak lagi pengusaha baru untuk menjalankan bisnis di bidang kopi dan kakao.

\section{Pusat Informasi dan Milestone.}

Tempat paling awal didatangi pengujung adalah pusat informasi. Dalam gedung ini, ditemukan beberapa hal , antara lain :

a) Pusat pelayanan dan informasi yang bertugas memberikan pelayanan dan informasi kepada pengunjung tentang berbagai objek yang berada di CCSTP. Petugas di sana juga bertugas menjual tiket dan mengatur perjalanan ke area kebun percontohan dengan menggunakan kereta flintstone.

b) Milestone atau tonggak sejarah Puslitkoka sejak didirikan pada tahun 1911 hingga saat ini dilengkapi dengan sejarah peralihan dari jaman Belanda sampai setelah Indonesia merdeka. Selain itu, masing-masing tonggak juga dituliskan capaian yang telah diperoleh Puslitkoka. c) Protofolio kerjasama riset dalam negeri dan luar negeri juga dapat ditemukan di sana. Serta penghargaan atas prestasi Puslitkoka baik dalam negeri dan luar negeri dipajang.

d) Pohon industri kopi dan kakao berupa bagan terpampang besar di dinding. Di sini dapat dipelajari dan dipahami bahwa terdapat banyak varietas kopi dan kakao di seluruh dunia. Di samping itu, Diseminasi hasil-hasil penelitian dan pengembangan teknologi dan kakao ditata. Berbagai jenis biji kopi dan kakao dipajang dalam toples sesuai dengan susunan pohon industri kopi dan kakao yang ada di dunia.

\section{Café dan Outlet Produk Kopi dan Kakao}

Hasil akhir dari ruang pengolahan kakao ini ada yang berupa cokelat bubuk, biasanya untuk bahan minuman cokelat ataupun kue-kue, dan cokelat batangan (bar) ataupun permen yang disajikan di café CCSTP. Ada berbagai produk olahan kopi dan kakao yang dijual di café. Untuk produk kopi yang ditawarkan di café ini adalah kopi ginseng, kopi latte, kopi cappuccino, kopi luwak dan kopi hitam dari berbagai jenis. Sedangkan untuk produk cokelat terdapat menu cokelat panas, cokelat susu, ice cream cokelat susu 
dan kedelai, serta olahan pastry cokelat lainnya seperti brownies, cupcake, permen dan roti isi cokelat. Untuk makan pendamping, café ini juga menyediakan spaghetti dan kentang goreng.

Tidak hanya makanan dan minuman siap saji saja yang ditawarkan, terdapat outlet yang menjual olahan kopi dan kakao yang siap untuk dibawa pulang seperti cokelat bubuk untuk minuman, kopi bubuk berbagai jenis, cokelat permen dari chocomilk hingga dark chocolate baik rasa original maupun campuran kacang mente.

Di dalam outlet ada produk menarik lainnya yaitu sabun yang terbuat dari bahan kopi yang berkhasiat untuk perawatan kulit. Ke depan, dapat dikembangkan berbagai produk perawatan kulit dari bahan yang sama.

\section{Guest House dan Homestay}

Sebagai pusat unggulan iptek kopi dan kakao, Puslitkoka menerima banyak kunjungan dari berbagai daerah di Indonesia juga dari mancanegara. Oleh karena itu, Puslitkoka yang berada di kawasan perkebunan kopi dan kakao menyediakan penginapan terutama bagi peneliti-peneliti yang berasal dari luar Jember.

Ditambah lagi dengan peningkatan status menjadi STP, mengharuskan
Puslitkoka untuk menciptakan entrepreneur baru di bidang kopi dan kakao melalui pelatihan-pelatihan untuk umum. Dengan adanya penginapan, akan peserta pelatihan untuk melakukan aktivitasnya selama di Pusliloka.

\section{Ruang Pertemuan}

Sebagai pusat penelitian dan Science Techno Park, Puslitkoka menyediakan ruang pertemuan untuk melakukan pelatihan-pelatihan baik bagi mitra kerja Puslitkoka maupun entrepreneur baru. Namun ruang pertemuan tersebut tidak setiap hari digunakan sehingga pihak CCSTP menawarkan ruang pertemuan tersebut untuk umum. Ruang pertemuan ini berstandar internasional dengan kapasitas 50 orang, model ruang membentuk huruf U lengkap dengan AC, LCD projector dan motorized screen, serta sound system.

\section{Strategi Promosi Eduwisata Puslitkoka}

CCSTP yang dikelola Puslitkoka merupakan eduwisata yang sukses di Jember. Kesuksesan ini dapat dilihat dari beberapa indikator berikut :

1) Peningkatan jumlah kunjungan.

2) Peningkatan penjualan produk olahan Puslit. 
CCSTP diresmikan pada bulan Mei 2016, dalam rentang waktu 16 bulan ini, terjadi peningkatan kunjungan ke Puslitkoka selama satu minggu penuh. Jumlah kunjungan melonjak tajam pada akhir minggu dan hari libur nasional sedangkan hari kerja tetap ada kunjungan tetapi tidak seramai akhir minggu. Lonjakan pengunjung di akhir pekan ini didominasi oleh pengunjung umum yang ingin rekreasi bersama keluarga dan sahabat. Mereka dapat menikmati sejuknya udara perkebunan dan disuguhkan pemandangan alam yang indah. Ini adalah daya tarik luar biasa yang dapat menarik pengunjung ke CCSTP. Di samping itu, pengunjung dapat menikmati kuliner di café ICCRI dan belanja oleholeh khas produk Puslitkoka sepuaspuasnya.

Sedangkan di hari kerja masih tetap melayani kunjungan. Kunjungan ini didominasi oleh kunjungan kelompok dan kunjungan study tour dari sekolah-sekolah di kabupaten Jember dan sekitarnya. Tujuan utama pengunjung adalah belajar segala hal yang berkaitan dengan kopi dan kakao. Pengunjung disuguhi pemandangan perkebunan yang sejuk dan indah yang merupakan area budidaya tanaman kopi dam kakao. Selain itu, CCSTP memiliki area penangkaran Rusa yang dapat dijadikan objek studi bagi siswa. Kemudian mereka diarahkan menuju pabrik kopi dan kakao untuk menyaksikan langsung proses pembuatan produk olahan kopi dan kakao. Sementara ini, pengunjung hanya dapat melakukan observasi melalui kaca. Pengunjung tidak diijinkan masuk area pabrik harus steril dan higienis. Di samping itu, keterbatasan prasarana untuk memasuki pabrik masih kurang untuk jumlah pengunjung yang relatif besar. Gedung transfer teknologi dan inkubasi bisnis menjadi area kunjungan wajib eduwisata. Harapannya informasi terkait dengan inkubasi bisnis ini dapat menambah wawasan dan inspirasi kepada pengunjung untuk mengembangkan bisnis dan menjadi entrepreneur muda di bidang kopi dan kakao.

Indikator berikutnya adalah terjadi peningkatan penjualan produk olahan Puslitkoka. Dengan dibukanya Puslitkoka untuk umum, pemintaan atas produk olahan kopi dan kakao meningkat tajam terutama produk olahan cokelat. Puslitkoka sempat mengalami kesulitan mendapatkan biji kakao terbaik yaitu cokelat fermentasi yang berkualitas sehingga Puslitkoka berinisiatif untuk mengadakan pembinaan kepada petani kakao dengan harapan menjadi mereka pemasok bahan baku cokelat untuk 
Puslitkoka. Sampai saat ini pun, Puslitkoka masih keawalahan untuk memenuhi kebutuhan cokelat untuk masyarakat Jember dan sekitarnya. Puslitkoka membuka dua outlet lainnya di kota Jember, pertama di kantor Pusat Penelitian Kopi dan Kakao di Jalan Panglima Besar Jendral Sudirman N0. 90 dan kedua, di Jalan Jawa (daerah kampus Universitas Negeri jember).

Meningkatnya permintaan cokelat ini dipengaruhi oleh peran CCSTP dalam mengedukasi masyarakat tentang manfaat cokelat. Selain itu, CCSTP secara tidak langsung menjadi ujung tombak Puslitkoka dalam mengembangkan Corporate Social Responsibility (CSR) sehingga tumbuh kepercayaan pada masyarakat akan produk yang dihasilkan memiliki standar yang tinggi, baik untuk kesehatan dan dijamin halal. Masyarakat berkunjung dan menyaksikan langsung proses pembuatan produk olahan kopi dan kakao merupakan testimoni yang kuat untuk mempromosikan produk-produk Puslitkoka dari mulut ke mulut. Inilah yang menjadi kunci sukses produk-produk Puslitkoka yaitu kepercayaan publik.

Kesuksesan Puslitkoka ini mengelitik peneliti untuk meneliti lebih lanjut bagaimana strategi yang dilakukan Puslitkoka untuk mempromosikan CCSTP kepada masyarakat. Dari wawancara yang peneliti bersama Ibu Diany Faila Sophia Hartantri, SP., M.Sc. yang biasa dipanggil dengan Bu Ila adalah sebagai berikut :

"Tidak banyak yang dilakukan Puslitkoka dalam hal promosi CCSTP. Yang kami lakukan promosi dari mulut ke mulut diawali dari seluruh pegawai di lingkungan Puslitkoka berupa testimoni di media sosial masingmasing maupun pendekatan personal seluruh pegawai kepada pengunjung Puslitkoka."

Kekuatan utama yang diandalkan CCSTP adalah promosi yang bersifat interpersonal yaitu informasi CCSTP disebarkan secara berangkai oleh siapa saja yang mengenal dan pernah singgah di Puslitkoka. Informasi yang bersifat personal ini lebih persuasif dan powerful dibandingkan iklan. Karena testimoni dari keluarga dan rekan kerja yang pernah berkunjung lebih dipercaya dibandingkan dengan media promosi lainnya.

Yang perlu digarisbawahi dalam hal ini adalah upaya seluruh pegawai Puslitkoka yang berkomitmen untuk mengembangkan CCSTP lebih besar lagi. Setiap pegawai bertanggung jawab untuk mempromosikan CCSTP. Mereka juga sadar bahwa dengan meningkatnya jumlah 
kunjungan, otomatis kesejahteraan seluruh pegawai juga meningkat.

Tidak hanya komunikasi personal yang dikembangkan. Media sosial menjadi bagian sarana promosi berikutnya. Untuk media sosial, lagi-lagi peran seluruh karyawan sangat penting. Mereka mengunggah promosi CCSTP melalui akun-akun pribadi yang dapat diakses oleh lebih banyak orang. Posting event, foto kegiatan, produk unggulan CCSTP menjadi menu utama di akun pegawai. Meskipun Puslitkoka memiliki website, tetapi informasi yang ada di dalamnya bersifat umum. Sedangkan masyarakat membutuhkan interaksi untuk bertanya lebih detail mengenai CCSTP.

Media sosial lain yang digunakan Puslitkoka dalam mempromosikan CCSTP adalah memaksimalkan akun IWJ (Informasi Warta Jember) yang memiliki banyak pengikut dan search engine tertinggi di Jember. Dengan bantuan IWJ, Puslitkoka dipromosikan di dunia maya. Menurut penuturan Ibu Ila bahwa Puslitkoka hanya bergabung di IWJ dan dan tidak menggunakan media sosial lainnya. Kalaupun menggunkan media lainnya, maka atas nama pribadi dari pegawai Puslitkoka yang ingin mempromosikan CCSTP. Penggunaan media sosial sifatnya hanya memberikan informasi saja dan masyarakat mengetahui keberadaan CCSTP. Oleh karena itu, Puslitkoka tidak mengekspos berlebihan di website maupun di akun media sosial komersial lainnya. Berfokus pada testimony individual karena lebih persuasif dan kuat dibandingkan dengan iklan.

Ketika peneliti menanyakan tentang divisi khusus yang menangani tentang Pemasaran atau Humas CCSTP kepada Ibu Ila, beliau mengatakan tidak ada divisi atau departemen khusus yang menangani itu. Puslitkoka hanya menunjuk satu orang pegawai yang dianggap memiliki ketrampilan berkomunikasi yang baik. Sebagai wisata edukasi, bidikan utama CCSTP adalah dunia pendidikan. Secara berkala, pegawai tersebut melakukan kunjungan ke sekolah-sekolah di kabupaten Jember untuk mempresentasikan keunggulan study tour ke CCSTP. Oleh karena itu, kunjungan CCSTP di hari kerja didominasi oleh pelajar dan mahasiswa.

Selain sekolah dan perguruan tinggi, target pasar berikutnya adalah instansi pemerintah. Presentasi yang ditawarkan adalah ruang rapat di tengah kawasan perkebunan. Sehingga tidak jenuh dalam mengikuti rapat. Sebenarnya ruang rapat dan guest ini merupakan fasilitas 
Puslitkoka untuk kepentingan pelatihan kopi dan kakao bagi peserta seluruh Indonesia. Namun tidak setiap hari pelatihan tersebut dilakukan. Untuk mengisi kekosongan di hari-hari tertentu, maka ruang rapat dan guest ini pun ditawarkan kepada masyarakat jika ingin menggunakan fasilitas tersebut.

\section{Analisis Komunikasi Pemasaran}

\section{Terpadu Eduwisata}

Berdasarkan paparan produk eduwisata Puslitkoka di atas, terdapat beberapa hal mendasar dikaitkan dengan strategi pemasaran eduwisata CCSTP antara lain :

1) Positioning. Puslitkoka mengangkat wisata edukasi CCSTP sebagai produk utamanya. Eduwisata ini merupakan inisiasi Puslitkoka untuk berbagi ilmu dan pengetahuan dengan masyarakat. Sehingga capaian Puslitkoka tidak hanya untuk kalangan tertentu tetapi juga untuk kepentingan umum. Selain itu, kebun percobaan yang luas dapat dinikmati oleh masyarakat Jember dan sekitarnya dimana masyarakat membutuhkan sarana rekreasi alam untuk mengurangi kepenatan kota.

Dilihat dari letaknya, CCSTP tidak jauh dari kota yaitu kurang lebih $20 \mathrm{~km}$ dari kota Jember dengan waktu tempuh 30 menit. Akses jalannya pun mudah dijangkau untuk berbagai jenis kendaraan. Sehingga CCSTP Puslitkoka dapat menjadi rekomendasi bagi masyarakat Jember untuk menghabiskan liburan bersama keluarga dan sahabat sambil belajar.

2) Segmentasi Pasar. Pasar CCSTP terbagi menjadi 3 segmen yaitu :

a) Pelajar dan mahasiswa, pada hari Senin hingga Jumat dengan tujuan eduwista. Pada hari kerja inilah pabrik beroperasi sehingga pengunjung dapat melihat proses pengolahan sekunder kopi dan kakao sebagai sarana belajar.

b) Umum, pada hari Sabtu dan Minggu serta hari libur nasional untuk rekreasi bersama keluarga dan sahabat menikmati keindahan dan kesejukan alam serta menikmati kuliner kopi dan cokelat.

c) Instansi, berdasarkan pesanan dan kesepakatan.

3) Harga. Harga menjadi fokus pelanggan. Harga yang ditetapkan Puslitkoka sangat terjangkau yaitu tiket masuk Rp 5.000 dan kereta Flintstone yang mengeliling perkebunana sebesar $\mathrm{Rp}$ 10.000. Penetapan harga yang terjangkau ini merupakan bagian dari komitmen Puslitkoka untuk mengedukasi masyarakat tentang tanaman kopi dan kakao sambil berwisata. 
4) Produk. Produk CCSTP adalah eduwisata. Dipilihnya eduwisata ini dikarenakan Kabupaten Jember tidak memiliki wisata berbasis edukasi. Terlebih lagi edukasi yang ditawarkan adalah segala hal yang berkaitan dengan kopi dan cokelat dimana dua jenis produk ini memiliki penikmat yang tinggi. Diimbangi dengan area perkebunan yang sejuk dan indah serta pabrik yang memiliki produk terbaik maka CCSTP telah memenuhi kategori multi wisata yaitu wisata edukasi, wisata alam dan wisata kuliner.

\section{5) Kepuasan pelanggan pelayanan prima.}

Kepuasan pelanggan adalah tujuan utama setiap usaha. Dengan fasilitas yang dimilikinya, Puslitkoka berupaya untuk memberikan setiap pengunjung. Saat ini, sumber daya manusia CCSTP adalah karyawan Puslitkoka yang dilatih untuk memberikan pelayanan prima kepada pengunjung. Secara berkala, mereka dilatih terutama bila ada kebijakan dan informasi penting untuk peningkatkan operasional CCSTP dan pelayanan prima bagi pelanggan.

Dilihat dari aspek promosi, CCSTP telah berhasil meningkatkan jumlah kunjungan hanya dengan tiga alat promosi yaitu komunikasi personal (promosi dari mulut ke mulut), media sosial IWJ dan personal selling (melakukan presentasi ke sekolah-sekolah dan instansi.

Ada berbagai ragam strategi komunikasi pemasaran terpadu yang dapat dilakukan oleh Puslitkoka seperti pemasangan iklan di berbagai media massa baik cetak, elektronik maupun media sosial, promosi penjualan dengan memberikan diskon berbagai produk, menyelenggarakan event, menjadi sponsor pada berbagai kegiatan di luar Puslitkoka, bahkan memaksimalkan fungsi kehumasan untuk pencitraan CCSTP Puslitkoka. Tetapi hal tersebut tidak dilakukan. Hal ini disebabkan oleh beberapa hal antara lain :

1) Puslitkoka baru bertransformasi dari Pusat Unggulan Iptek (PUI) menjadi Science Techno Park (STP). Setidaknya dibutuhkan waktu selama 2 tahun untuk membenahi perubahan ini. Dikhawatirkan promosi besar-besaran tidak dibarengi dengan kesiapan seluruh karyawan Puslitkoka dalam memberikan pelayanan prima kepada pengunjung akan merugikan perkembangan CCSTP ke depan.

2) Produk-produk terbaik Puslitkoka belum mampu memenuhi kebutuhan pelanggan. Kapasitas pabrik yang relatif kecil dan terbatasnya bahan baku pilihan berstandar SNI juga menjadi pertimbangan Puslitkoka untuk tidak mengekspos produk-produk secara berlebihan. 
3) Puslitkoka kewalahan dengan produk. Puslitkoka adalah lembaga swasta tingginya animo masyarakat Jember dan sekitarnya mengunjungi CCSTP meskipun dengan media promo yang terbatas. Sementara ini fasilitas-fasilitas pendukung di area CCSTP belum dimaksimalkan. Secara bertahap, CCSTP akan menambah berbagai fasilitas untuk pengunjung sehingga pengunjung puas berwisata di CCSTP.

Kesiapan Puslitkoka menjadi syarat mutlak bagi keberlangsungan CCSTP di masa datang. Penggunaan media promo yang berlebihan akan menghambat perkembangan CCSTP itu sendiri. Dengan masa transformasi selama 2 tahun, CCSTP menemukan pola manajemen yang lebih baik.

\section{Hambatan Komunikasi Eduwisata Puslitkoka}

Pesatnya perkembangan CCSTP bukan berarti tanpa hambatan. Menurut Ibu Ila, ada dua faktor penting yang menghambat eduwisata Puslitkoka antara lain masalah pendanaan dan sumber daya manusia. Berikut penjelasannya :

\section{1) Pendanaan}

Dibutuhkan dana yang besar untuk menambah fasilitas-fasilitas dan sirkulasi dengan pengelolaan keuangan secara mandiri dan tidak mengandalkan bantuan dari pemerintah. Sementara ini Puslitkoka sangat selektif dalam menerima investasi dari pihak luar karena dikhawatirkan campur tangan investor dapat mempengaruhi tugas utama Puslitkoka sebagai pusat penelitian kopi dan kakao. Oleh karena itu, Puslitkoka terus berupaya memperoleh dana yang cukup dari keuntungan CCSTP, kerjasama penelitian, kerjasama dengan perusahaan di bidang kopi dan kakao, serta pelatihan entrepreneur baru.

\section{2) Sumber daya manusia}

Sumber daya manusia yang mengelola CCSTP masih terbatas. Rekruitmen karyawan baru tidak menjadi prioritas manajemen. Pengoptimalan kerja karyawan pilihannya. CCSTP merupakan usaha baru yang sedang proses membentuk sistem manajerial yang tepat. Oleh karena itu, banyak karyawan yang memiliki rangkap bidang pekerjaan. Selain meneliti, juga mengelola CCSTP secara bergiliran. Padahal kompetensi utama mereka adalah peneliti. Hal ini berdampak pada kurang primanya karyawan dalam melayani dan memuaskan pelanggan.

Adapun hambatan komunikasi yang terjadi dalam upaya manajemen 
menghadapi transformasi fungsi dari Pusat Unggulan Ipteks kopi dan kakao menjadi Science Techno Park (eduwisata) dikarenakan secara manajemen sumber daya manusia, karyawan Puslitkoka selain melakukan penelitian juga dimaksimalkan sebagai tenaga operasional di CCSTP. Tumpang tindih tugas ini membuat karyawan kurang fokus dalam mengerjakan tugas-tugasnya. Kelebihan beban tugas berpotensi terjadi miscommunication baik komunikasi yang bersifat horizontal yaitu antar rekan kerja maupun komunikasi yang bersifat vertikal yaitu antara lini atas dan lini bawah.

Secara sadar, seluruh karyawan yang bertugas menyadari bahwa CCSTP yang baru dirintis membutuhkan dukungan penuh. CCSTP adalah salah satu unit usaha di Puslitkoka yang mendukung unit usaha lainnya. Sebagai usaha rintisan, manajemen dalam CCSTP mengikuti perkembangan yang ada. Dalam masa transisi wajar bila terjadi miscommunication dalam manajemen karena sistem belum terbentuk. Perbaikan sistem dalam manajemen terus ditingkatkan hingga operasionalisasi kinerja CCSTP dapat berjalan lancar. Masa transisi dua tahun akan berakhir di pertengahan tahun 2018 mendatang. Evaluasi kinerja CCSTP akan ditinjau kembali. Dengan demikian kekurangan dan hambatan dalam manajemen CCSTP dapat diminimalisir sehingga CCSTP menjadi salah satu unit usaha unggulan Puslitkoka yang produktif di masa mendatang.

\section{SIMPULAN}

Berdasarkan hasil analisa penelitian dan pembahasan, maka dapat disimpulkan beberapa hal berikut :

1) Strategi komunikasi pemasaran terpadu CCSTP menggunakan tiga alat promosi yaitu komunikasi personal (promosi dari mulut ke mulut), media sosial IWJ dan personal selling (melakukan presentasi ke sekolah-sekolah dan instansi. Diantara tiga alat promosi ini yang paling efektif adalah komunikasi personal dimana pendekatan personal dalam lebih mempersuasi calon pengunjung secara optimal.

2) Hambatan komunikasi yang terjadi karena ada rangkap tugas dalam manajemen CCSTP dimana selain tugas penelitian juga mengelola CCSTP. Rangkap tugas ini berpotensi terjadi miscommucation dalam manajemen.

\section{DAFTAR PUSTAKA}

Aloweri, 2013, Komunikasi Serba Ada Serba Makna, KencanaPrenada Media Group, Jakarta 
Brannan, Tom, 1999, Intergrated Marketing Communication, Penerbit Gramedia, Jakarta

Kotler, Philip, 2009, Manajemen Pemasaran, Indeks, Jakarta

Pawito, 2007, Penelitian Komunikasi Kualitatif, LKiS Pelangi Aksara, Yogyakarta

Purwanto, Djoko, 2002, Komunikasi Bisnis, Penerbit Erlangga, Jakarta

Rakhmat, Jalaludin, 2004, Psikologi Komunikasi, Rosda Karya, Bandung

Shimp, Terence A, 2014, Komunikasi Pemasaran Terpadu, Penerbit Salemba empat, Jakarta
Umami, Zahrotul, 2015, Social Strategy pada Media Massa untuk Promosi Pariwisata Daerah Istimewa Yogyakarta, Jurnal Interaksi Volume 4 Nomor 2 Juli 2015, Universitas Diponegoro, Semarang https://ejournal.undip.ac.id/index.ph p/interaksi/article/view/9763

Yoeti, Oka A, 1990, Pengantar Ilmu Pariwisata, Penerbit Angkasa, Bandung

-----, 1990, Pemasaran Pariwisata, Penerbit Angkasa, Bandung

\section{Internet :}

http://tc.iccri.net/ diunduh pada tanggal 19 November 2017 